\title{
US BIOTECHNOLOGY COMPANIES WITH SUBSTANTIAL NEUROSCIENCE R \& D PROGRAMMES
}

\section{Therapeutics/Diagnostics}

\section{Alanex Corporation, San Diego, CA}

Status: privately held

Corporate interests: use of computational molecular design and synthetic chemistry to develop smallmolecule, non-peptide drugs that either mimic or inhibit the actions of peptides. The company is developing a new class of molecules based on the neurotransmitter Neuropeptide Y. Collaboration with Amgen Inc.

\section{Athena Neurosclences Inc., South San}

Francisco, CA

\section{Status: publicly held}

Corporate interests: development of therapeutic and diagnostic products for neurological diseases and disorders, with a leading research effort in Alzheimer's disease in collaboration with Eli Lilly. In the field of brain inflammation, the company is focusing on developing treatments for head injury, multiple sclerosis and stroke.

\section{Cambridge NeuroSclence Inc., Cambridge, MA}

Status: publicly held

Corporate interests: development of ion-channel blockers for the treatment and prevention of brain damage resulting from stroke, traumatic brain injury and surgery, and glial growth factors for the treatment of peripheral neuropathies and degenerative muscle disorders, such as muscular dystrophy. Cephalon Inc., West Chester, PA

Status: publicly held

Corporate interests: development of treatments for neurodegenerative diseases and disorders such as amyotrophic lateral sclerosis (ALS), Alzheimer's disease and narcolepsy.

CoCensys Inc., Irvine, CA

Status: publicly held

Corporate interests: development of CNS drugs to treat neurological and psychiatric disorders such as epilepsy, anxiety and sleep disorders, and cerebral ischaemia caused by stroke and head injury. Alliance with Ciba Pharmaceutical.

Cypros Pharmaceutical Corporation, Carlsbad, CA Status: publicly held

Corporate interests: using an "in-licensing" approach, the company has a drug in clinical trials for the treatment of stroke and/or traumatic head injury. Research involves development of an adenosine metabolism inhibitor, neuronal calcium channel and glial chloride channel blockers.
Geron Corporation, Menlo Park, CA

Status: privately held

Corporate interests: development of drugs for the treatment of age-related degenerative diseases and cancer.

Gllatech Inc., Cleveland, $\mathrm{OH}$

Status: privately held

Corporate interests: based on its glial cell research, the company is developing therapeutic products with potential applications in areas such as the treatment of Alzheimer's disease, anxiety and coma. Gliatech last month announced plans to collaborate with Janssen Pharmaceutica N.V.

Neurex Corporation, Menlo Park, CA

Status: publicly held

Corporate interests: using a targeted licensing-in strategy, as well as its own discovery programmes, the company is building a portfolio of products in the acute care area. Neurex's main discovery effort is focused on a proprietary neuromodulation tech nology, which enables the selective blocking of different classes of neuron-specific calcium channels, thereby regulating the release of specific neuro transmitters.

\section{Neurogen Corporation, Branford, CT}

Status: publicly held

Corporate interests: development of products for the treatment of neuropsychiatric disorders. Five year R \& D agreement with Pfizer Inc. in the GABA receptor area for the development of drugs to treat anxiety.

Regeneron Pharmaceuticals Inc., Tarrytown, NY

Status: publicly held

Corporate interests: use of neuronal growth pro teins for the treatment of degenerative and traumat ic neurological disorders, such as Alzheimer's, Parkinson's and Huntington's diseases and ALS.

SIBIA Inc., La Jolla, CA

Status: privately held

Corporate interests: development of therapeutics for neurodegenerative diseases and other CNS conditions, including Alzheimer's disease and othe dementias, epilepsy, stroke and Parkinson's disease. Corporate partnerships with Eli Lilly \& Co. and Ciba-Geigy Ltd.

Slgnal Pharmaceuticals Inc., San Diego, CA

Status: privately held

Corporate interests: development of small-molecule therapeutics that regulate the transcription factors involved in the progression of a number of inflammatory, viral and neurological diseases. Disease targets include Alzheimer's and Parkinson's disease, stroke, trauma and ALS.

Spectra Biomedical Inc., Menlo Park, CA

Status: privately held

Corporate interests: development of diagnostics and therapeutics based on an understanding of the genetics of human diseases and traits. The company's initial focus is on neuropsychiatric disorders, particularly migraine, anxiety and depression. Collaborative research agreement with Glaxo Holdings plc in the field of migraine therapeutics.

Sugen Inc., Redwood Clty, CA

Status: privately held

Corporate interests: receptor-based drug discovery and development with a primary emphasis on the tyrosine kinases and phosphatase receptor systems.

Synaptic Pharmaceutical Corporation,

\section{Paramus, NJ}

Status: privately held

Corporate interests: discovery of novel G-proteincoupled receptors expressed in the CNS.

Synergen Inc., Boulder, CO

Status: publicly held

Corporate interests: development of neurotrophic factors for the treatment of degenerative neurological diseases and conditions such as ALS, Parkinson's and Alzheimer's diseases. Neuroscience joint venture with Syntex (USA) Inc.

\section{Drug delivery}

\section{Alkermes Inc., Cambridge, MA}

Status: publicly held

Corporate interests: development of drug delivery technologies. The company's leading product candidate, a receptor-mediated permeabilizer, is being developed to improve the treatment of brain tumours and infections of the CNS

Alza Corporation, Palo Alto, CA

Status: publicly held

Corporate interests: development of therapeutic systems of drug delivery. In the neuroscience area, Alza is concentrating on disorders of the CNS (e.g. pain management, psychiatry and neurology).

CytoTherapeutics Inc., Providence, RI

Status: publicly held

Corporate interests: development of implantable delivery systems for biologically active and gene therapy products for the treatment of CNS diseases and other chronic disorders.

This is not a comprehensive list but instead provides a guide to the number and types of companies in the neuroscience area. Other biotechnology companies such as Amgen Inc. and Genentech Inc. have neuroscience programmes, as do most US pharmaceutical companies.

the same idea is tough to do in academic institutions.

Switching fields can also be tricky in an academic setting. A PhD pharmacologist by training, Peroutka says that it would have been impossible for him to get federal funding to move from pharmacology to genetics. "Industry allows you to really go where you need to go scientifically and provides the resources to do that in a way that's just not possible in academia." Peroutka, a former director of neuroscience at Genentech Inc., founded Spectra Biomedical last year to identify the molecular genetic basis of migraine and other neuropsychiatric diseases such as anxiety and depression.

For those academic scientists who are taking a hard look at a career in biotechnology, the attractions are plain to see: an end to grant writing and the often heavy administrative burdens of faculty life. The option of owning stock in a company can't hurt either. It also provides the opportunity to be a team player in an entrepreneurial enterprise and the chance to see something practical evolve from their research efforts. The downside is the high degree of risk (the company could go 'belly up'), but with risk comes the potential for reward, says Gibson.

The question of academic freedom freedom to publish, attend scientific meetings and maintain close academic ties is a commonly voiced concern among scientists contemplating a move. Company policy may vary on this but, at best, researchers should expect to experience some delays when publishing.

Many companies encourage employees to foster academic collaborations. And, although Athena Neurosciences' Groom encourages his employees to do likewise, he draws the line at them holding adjunct appointments (with the exception of physicians, whom he says should maintain some 'hands-on' experience with patients). "Having someone with one foot in academia and one foot in industry is not good", he says, particularly as some scientists find it hard enough to break with academic tradition.

In the end, those who succeed in industry are the ones who are most comfortable working in an environment where change is constant, says Gibson. As Peroutka puts it, scientific adaptability is the key.

Diane Gershon is Product Review Editor of Nature. 